\title{
Faktor-Faktor yang Mempengaruhi Kesulitan dan Minat Belajar Mahasiswa Jurusan Pendidikan Biologi Universitas Sulawesi Barat
}

\author{
Jirana $^{1)}$, Syamsiara Nur ${ }^{2)}$, Nurmiati ${ }^{3)}$ \\ 1,2,3 Prodi Pendidikan Biologi-FMIPA, Universitas Sulawesi Barat \\ e-mail : jiran_taheer@yahoo.co.id
}

\begin{abstract}
Abstrak
Penelitian dilakukan dengan menggunakan metode survei yang bertujuan untuk mengetahui faktor-faktor yang menyebabkan kesulitan dan minat belajar mahasiswa biologi unsulbar angkatan 2013 pada mata kuliah Fisiologi Tumbuhan. Data yang berupa hasil belajar dikumpulkan dengan menggunakan tes objektif, sedangkan data yang berupa respon kesulitan dan minat belajar mahasiswa berupa kuesioner, observasi, dan wawancara. Analisis data dengan menggunakan tes objektif diperoleh hasil menunjukkan bahwa mahasiswa lebih banyak mendapat nilai $C$ yaitu dengan persentase 52, 94\% dan nilai D dengan 11,67\%. Disimpulkan bahwa pemahaman mahasiswa tentang konsep Fisiologi Tumbuhan tergolong masih rendah. Hal ini tentu saja disebabkan karena kesulitan belajar mengenai konsep Fisiologi Tumbuhan dan kurangnya minat belajar mahasiswa di mana penyebab tersebut berasal faktor internal yaitu dari diri mahasiswa sendiri dengan persentase masing-masing 52,94\% dan 47,06\%.
\end{abstract}

Kata Kunci: Kesulitan belajar, Minat belajar, Mahasiswa biologi

\section{PENDAHULUAN}

Proses pembelajaran merupakan hal yang kompleks yang melibatkan dua pelaku utama yaitu pendidik dan mahasiswa. Kegiatan belajar mahasiswa merupakan akibat dari tindakan pendidik yang melakukan pengorganisasian belajar, penyajian bahan belajar dengan pendekatan pembelajaran tertentu, dan melakukan evaluasi hasil belajar. Dalam belajar, mahasiswa menghadapi masalah-masalah baik secara intern maupun secara ekstern. Jika mahasiswa tidak dapat mengatasi masalahnya, maka ia tidak belajar dengan baik.

Gagne dalam Trianto (2009) menyatakan bahwa untuk terjadinya belajar pada diri mahasiswa diperlukan kondisi belajar, baik kondisi internal maupun kondisi ekternal. Untuk membantu mahasiswa mencapai berbagai kompetensi yang diharapkan, pelaksanaan pembelajaran perlu diusahakan agar interaktif, inspiratif, menyenangkan, menantang, memotivasi mahasiswa untuk berpartisipasi aktif, kreativitas, dan kemandirian sesuai dengan bakat, minat, dan perkembangan fisik serta psikologis mahasiswa.

Keberhasilan proses pembelajaran dapat dilihat dari prestasi belajar yang dicapai mahasiswa. Kriteria keberhasilan pendidik dan mahasiswa dalam melaksanakan program pembelajaran dilihat dari kompetensi dasar yang dimiliki oleh mahasiswa. Mahasiswa sering menghadapi kesulitan atau masalah dan membutuhkan bantuan serta dukungan dari lingkungan sekitarnya untuk menyelesaikan kesulitan atau masalah tersebut. Agar dapat membantu mahasiswa secara tepat perlu diketahui terlebih dahulu apakah kesulitan atau masalah yang dihadapi mahasiswa tersebut, baru kemudian dianalisis dan dirumuskan pemecahannya (Depdiknas, 2007). Salah satu peranan pendidik berkaitan dengan kompetensinya adalah mampu melakukan diagnosis terhadap perilaku awal mahasiswa. Menurut Rusman (2010) pada 
dasarnya pendidik harus mampu membantu kesulitan-kesulitan yang dihadapi mahasiswa dalam proses pembelajaran.

Anak berkesulitan belajar umum secara nyata mengalami kesulitan dalam tugas-tugas akademik khusus maupun umum, baik disebabkan oleh adanya disfungsi neurologis, proses psikologi dasar maupun sebab-sebab lain sehingga prestasi belajarnya rendah. Anak berkesulitan belajar tidak sama dengan anak tunagrahita. Anak berkesulitan belajar umum biasanya ditandai dengan prestasi belajar yang rendah untuk hampir semua mata pelajaran atau nilai rata-rata jauh di bawah rata-rata kelas disebabkan karena IQ yang rendah. Pada umumnya anak yang mengalami kesulitan belajar karena mempunyai inteligensi di bawah rata-rata yakni dengan IQ antara 70-90.

Anak berkesulitan belajar kemungkinan juga mengalami gangguan fisik, sosial dan mental yang ringan sehingga cukup mengganggu mereka dalam menangkap pelajaran. Anak yang mengalami gangguan penglihatan jauh akan merasa kesulitan jika ditempatkan di tempat duduk paling belakang, demikian juga dengan anak yang mengalami gangguan pendengaran ringan. Anak yang memilki inteligensi di bawah rata-rata (slow learner) memerlukan penjelasan dengan menggunakan berbagai metode dan berulang-ualang agar mereka dapat memahami pelajaran dengan baik. Anak yang mengalami gangguan tingkah laku memerlukan perhatian yang cukup terhadap persoalan sosial yang dihadapinya agar dapat mengkonsentrasikan diri pada pelajaran.

Seseorang yang mengalami kesulitan belajar menurut Burton (dalam Shadiq, 2007) adalah orang yang menunjukkan kegagalan tertentu dalam mencapai tujuan-tujuan belajarnya. Kegagalan ini dapat dilihat, apabila Dalam batas waktu tertentu yang bersangkutan tidak mencapai ukuran tingkat keberhasilan atau tingkat penguasaan minimal dalam pelajaran tertentu, tidak dapat mengerjakan atau mencapai prestasi semestinya, tidak dapat mewujudkan tugas-tugas perkembangan, tidak berhasil mencapai tingkat penguasaan yang diperlukan sebagai prasyarat bagi kelanjutan pada tingkat pelajaran berikutnya.

Muhibbin (2010), minat secara sederhana berarti kecederungan atau kegairahan yang tinggi atau keinginan yang besar terhadap sesuatu. Jadi, dalam proeses belajar mahasiswa harus mempunyai minat. Kesukaan untuk mengikuti kegiatan belajar yang sedang berlangsung karena dengan minat dapat mendorong mahasiswa menunjukkan perhatiannya, aktifitasnya dan partisipasinya mengikuti kegiatan belajar yang sedang berlangsung.

Minat merupakan salah satu aspek psikis yang ada pada setiap manusia yang bersifat relatif. Hilgard dalam Slameto (2010) merumuskan minat adalah interest is persisting tendency to pay attention to andenjoy some activity or content (minat adalah kecenderungan tetap untuk memperhatikan dan mengenang beberapa kegiatan). Kegiatan yang diminati seseorang, akan diperhatikan terus menerus disertai dengan rasa senang.

Minat dapat diartikan sebagai suatu kondisi yang terjadi apabila seseorang melihat ciriciri atau arti sementara situasi yang dihubungkan dengan keinginan atau kebutuhankebutuhannya sendiri (Sardiman, 2009). Minat seseorang terhadap suatu obyek akan membawa suatu kecenderungan untuk bergaul lebih dekat dengan obyek yang diminatinya. Kenyataan ini berlaku dalam belajar ketika mahasiswa memiliki minat yang besar terhadap mata kuliah biologi, maka secara otomatis mahasiswa dapat berperan aktif dalam pembelajaran biologi, baik secara tindakan maupun secara mental (Djaali, 2007).

Mengutip, Cooney, Davis, dan Henderson (Shadiq, 2007) mengelompokkan sumber kesulitan itu menjadi lima faktor, yaitu: faktor fisiologis, faktor sosial, faktor emosional, faktor intelektual, dan faktor pedagogis. Untuk mengetahui kesulitan-kesulitan dalam pembelajaran para pendidik hanya mengandalkan pada intuisi atau kebiasaan sehari-hari. Penelitian relevan oleh Anas Arfandi (2014) tentang faktor-faktor yang mempengaruhi kesulitan belajar mahasiswa pendidikan Teknik Sipil FT UNM diperoleh bahwa kesulitan belajar mahasiswa jurusan PTSP FT UNM banyak disebabkan oleh faktor internal seperti kondisi kesehatan dan psikologis, sementara faktor eksternal berupa lingkungan sosial dan instrumental di kampus sudah baik. 
Penelitian ini bertujuan untuk mengetahui kesulitan dan minat belajar mahasiswa jurusan Pendidikan Biologi di Universitas Sulawesi Barat yang diharapkan dapat menjadi bahan pertimbangan bagi pihak Unsulbar khususnya prodi pendidikan biologi untuk perbaikan dan pemberian perhatian terhadap mahasiswa.

\section{METODE PENELITIAN}

Penelitian dilakukan dengan menggunakan metode survei yang bertujuan untuk mengetahui faktor yang mempengaruhi kesulitan belajar dan minat belajar mahasiswa biologi prodi pendidikan biologi Universitas Sulawesi Barat. Penelitian ini akan dilaksanakan pada bulan Juli-Oktober 2015 di Universitas Sulawesi Barat. Subjek penelitian adalah mahasiswa biologi prodi pendidikan biologi Universitas Sulawesi Barat angkatan 2013 Kelas A.Tahap Perencanaan. Tahapan Perencanaan dilakukan dalam beberapa kegiatan, yaitu: pertama dengan observasi dan penentuan masalah yang akan diteliti berdasarkan fenomena yang terjadi. Observasi atau pengamatan dilakukan terhadap mahasiswa dan mahasiswi jurusan biologi prodi pendidikan Universitas Sulawesi Barat, tujuannya untuk mengetahui masalah-masalah yang terdapat di Universitas Sulawesi Barat khususnya pada prodi pendidikan biologi. Masalah yang timbul yang dianggap dapat menurunkan semangat belajar mahasiswa akan diangkat sebagai variabel penelitiaan. Kedua denagn melakukan studi kepustakaan untuk memperoleh gambaran yang jelas yang berkaitan dengan masalah yang akan diteliti.

Tahap Persiapan dengan mengajukan proposal pada Ketua Lembaga Penelitian Unsulbar, Penyetujuan proposal oleh Ketua Lembaga Penelitian Unsulbar, Penyusunan instrumen. Tahap kedua dengan pelaksanaan yang merupakan tahap pengumpulan data. Teknik pengumpulan data merupakan langkah yang paling penting dalam penelitian karena tujuan utama dari penelitian adalah untuk mendapatkan data. Untuk memperoleh data yang akurat mengenai hal yang diteliti, maka penulis akan melakukan pengumpulan data melalui Penyebaran kuesioner bentuk berupa seperangkat pernyataan tertulis yang dibagikan kepada responden untuk dijawab, yang berkaitan dengan kesulitan dan minat belajar mahasiswa prodi pendidikan biologi, penelusuran hasil belajar mahasiswa bertujuan untuk melihat kemampuan belajar mahasiswa dalam hal pengetahuan, kemudian membandingkan hasil belajar dengan kesulitan dan minat belajar, wawancara dengan mahasiswa tentang informasi yang berkaitan dengan penelitian diharapkan dapat memperoleh informasi lebih lengkap tentang kesulitan belajar yang mereka alami sehingga data yang dikumpulkan menjadi lebih akurat.

Jenis wawancara yang dilakukan adalah wawancara tertutup dan wawancara terbuka terhadap mahasiswa dan mahasiswi sebagai responden dalam penelitian. Dokumentasi (pengambilan gambar) merupakan pelengkap dari penggunaan metode observasi dan wawancara agar kredibilitas hasil penelitian semakin tinggi.

Tahap Pengolahan Prosedur yang dilakukan dalam proses pengolahan data yaitu mengecek kelengkapan jumlah kuesioner yang terkumpul dan kelengkapan pengisian kuesioner yang telah diisi oleh responden serta merekap semua data yang telah diperoleh.

Data yang diperoleh pada penelitian ini selanjutnya dianalisis dengan menggunakan statistik deskriptif berdasarkan persentase dengan menggunakan rumus sebagai berikut: Keterangan:

$$
P=\frac{F}{N} 100 \%
$$

$\mathrm{P} \quad=$ Persentase

$\mathrm{F} \quad=$ Frekuensi

$\mathrm{N} \quad=$ Jumlah item

Melakukan observasi terhadap mahasiswa jurusan biologi Universitas Sulawesi Barat untuk mengidentifikasi permasalahan yang dialami oleh mahasiswa untuk menghimpun informasi permasalahan di jurusan pendidikan biologi. 
JURNAL SAINTIFIK VOL. 1 NO. 2, JULI 2015

Penulis memilih beberapa masalah mendasar dalam proses pembelajaran. Pada kegiatan pelaksanaan dilakukan observasi, penyebaran angket kepada responden, wawancara dan dokumentasi. Data hasil yang diperoleh akan dianalisis berdasarkan analisis deskriptif.

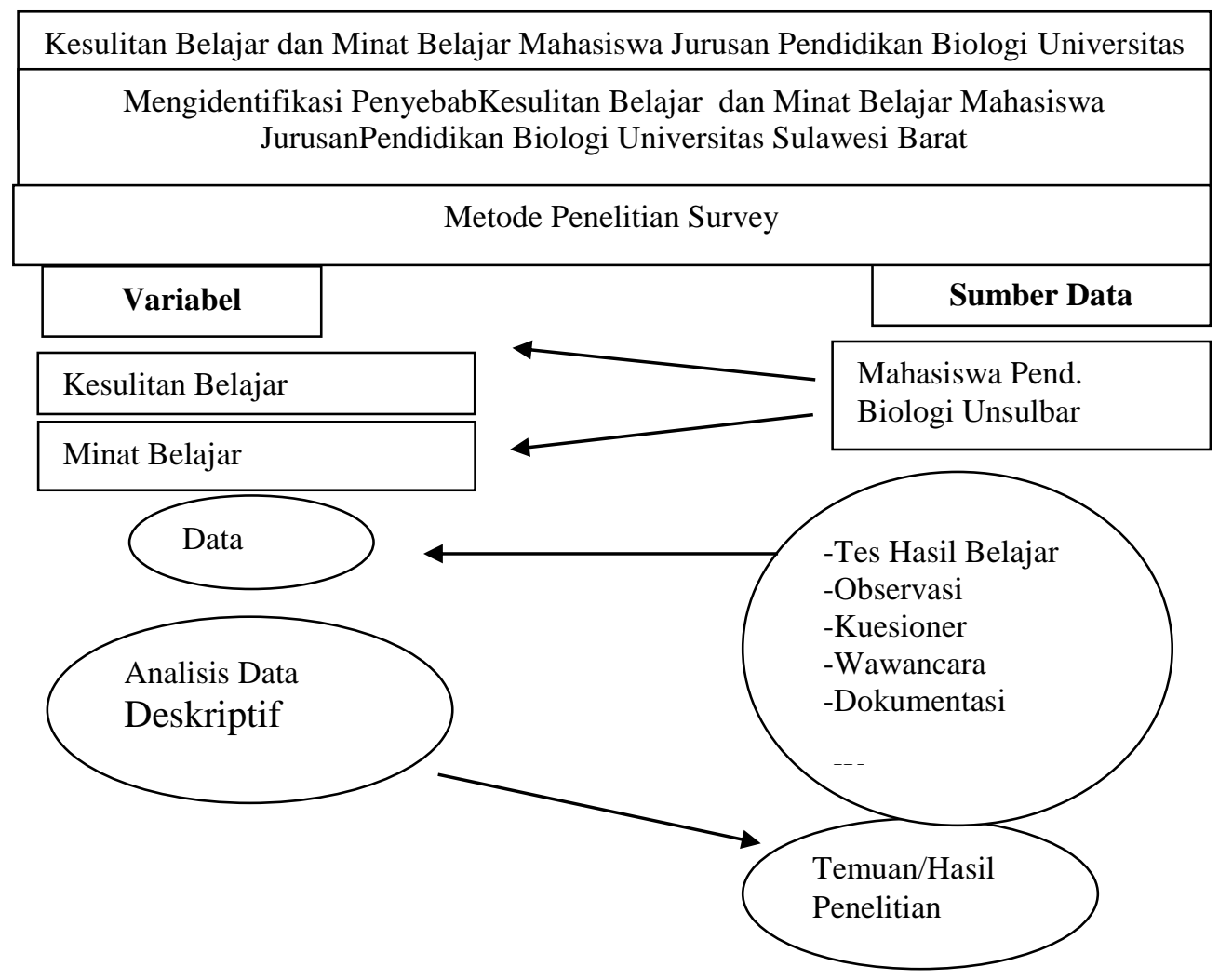

Gambar 1. Bagan Alur Rancangan Penelitian

\section{HASIL DAN PEMBAHASAN}

\subsection{Hasil Belajar}

Aspek kesulitan siswa dalam memahami konsep Fisiologi Tumbuhan pada tahap soal dapat dilihat dari hasil jawaban peserta tes yang berupa pemahaman konsep yang terdapat pada Tabel 4.1 berikut:

Tabel 1. Frekuensi dan Presentase pemahaman konsep Mahasiswa

\begin{tabular}{c|c|c|c|c|}
\hline Rentang Skor & Frek & $\begin{array}{c}\text { Persen } \\
(\%)\end{array}$ & Nilai & Kategori \\
\hline $80-100$ & 0 & 0 & A & Sangat Tinggi \\
\hline $70-79$ & 6 & 35,29 & B & Tingg \\
\hline $65-69$ & 9 & 52,94 & C & Sedang \\
\hline $50-60$ & 2 & 11,76 & D & Rendah \\
\hline 0 & 0 & 0 & E & Sangat Rendah
\end{tabular}

Tabel 1 menunjukkan bahwa terdapat 6 mahasiswa yang mempunyai nilai B pada mata kuliah Fisiologi Tumbuhan dengan nilai persentase 35,29\%, 9 mahasiswa nilai $\mathrm{C}$ dengan 
persentase $11,76 \%$ dan 2 mahasiswa dengan nilai D persentase $11,76 \%$, kedua mahasiswa ini termasuk golongan tidak lulus.

3.2 Kesulitan Belajar

Selain hasil belajar, penulis juga memperoleh data hasil penyebaran kuesioner dari mahasiswa. Kesulitan belajar yang dialami mahasiswa jika dilihat dari 4 indikator dari kesulitan belajar dapat dilihat pada Tabel 4.2 berikut:

Tabel 2. Hasil Penyebaran Kuesioner Kesulitan Belajar Mahasiswa

\begin{tabular}{l|l|l|l|c}
\hline & \multirow{2}{*}{$\begin{array}{l}\text { Faktor-Faktor yang } \\
\text { Mempengaruhi Kesulitan }\end{array}$} & \multicolumn{2}{|l|}{ Pemyataan } & $\begin{array}{c}\text { Persentase } \\
(\%)\end{array}$ \\
\cline { 3 - 4 } & Belajar & Ya & Tidak & \\
\hline 1 & Diri Sendin & $77,04 \%$ & $22,96 \%$ & 52,94 \\
\hline 2 & Lingkungan Keluarga & $52,94 \%$ & $47,06 \%$ & 11,76 \\
\hline 3 & Lingkungan Sekolah & $55,29 \%$ & $44,71 \%$ & 29,41 \\
\hline 4 & LingkunganMasyarakat & $50 \%$ & $50 \%$ & 23,93 \\
\hline
\end{tabular}

Tabel 2 menunjukkan bahwa faktor yang mempengaruhi kesulitan belajar mahasiswa biologi kelas A angkatan 2013 pada materi Fisiologi Tumbuhan berasal dari 4 aspek yaitu dari diri sendiri, keluarga, sekolah, dan lingkungan masyarakat. Aspek diri sendiri mempunyai persentase tertinggi sebagai faktor yang mempengaruhi kesulitan belajar yaitu sebanyak $52,94 \%$, menyusul lingkungan sekolah $29,41 \%$, Lingkungan masyarakat 23,93\% dan lingkungan keluarga sebanyak $11,76 \%$.

\subsection{Minat Belajar}

Minat belajar yang dialami mahasiswa jika dilihat dari 4 indikator dari kesulitan belajar dapat dilihat pada Tabel 3 berikut:

Tabel 3. Hasil penyebaran kuesioner Mahasiswa

\begin{tabular}{l|l|c|c|c}
\hline No & \multirow{2}{*}{$\begin{array}{l}\text { Faktor-Faktbr yang } \\
\text { MempengaruhiKesulitan }\end{array}$} & \multicolumn{2}{|c|}{ Pemyataan } & \multirow{2}{*}{$\begin{array}{c}\text { Persentass } \\
(\%)\end{array}$} \\
\cline { 3 - 4 } & Belajar & Ya & Tidak & \\
\hline 1 & Jasmani, Psikologis & $62,50 \%$ & $37,50 \%$ & 47,06 \\
\hline 2 & Keluarga & $48,52 \%$ & $47,06 \%$ & 23,53 \\
\hline 3 & Sekolah & $62,75 \%$ & $37,25 \%$ & 35,29 \\
\hline 4 & Masxarakat & $55,88 \%$ & $44,12 \%$ & 11,76 \\
\hline
\end{tabular}

Tabel 4.3 menunjukkan bahwa faktor yang mempengaruhi minat belajar mahasiswa biologi kelas A angkatan 2013 pada materi Fisiologi Tumbuhan berasal dari 4 aspek yaitu dari aspek jasmani dan psikologi, keluarga, sekolah, dan masyarakat. Aspek psikologi mempunyai persentase tertinggi sebagai faktor yang mempengaruhi minat belajar yaitu sebanyak $47,06 \%$, menyusul lingkungan sekolah $35,29 \%$, keluarga $23,53 \%$ dan masyarakat sebanyak $11,76 \%$.

\subsection{Observasi}

Hasil observasi proses pembelajaran Fisiologi Tumbuhan, ada beberapa hal yang ditemukan yang dapat menjadi faktor penyebab kesulitan dan minat belajar pada mahasiswa, baik dilihat dari kegiatan mahasiswa, kegiatan dosen, kondisi atau keadaan kelas.

- Kegiatan Mahasiswa. Terdapat beberapa mahasiswa yang tidak mengikuti kegiatan proses pembelajaran dengan serius, hal ini ditandai dengan kurangnya mahasiswa yang mengajukan dan menjawab pertanyaan. 
- Keadaan kelas. Kurangnya media pembelajaran yang dapat digunakan khususnya pada konsep fisiologi tumbuhan sehingga berdampak pada pada kurangnya ketertarikan dan minat mahasiswa dalam proses pembelajaran. Mahasiswa kurang komunikatif.

Terdapat banyak faktor yang dapat mempengaruhi kesulitan belajar. Rendahnya prestasi belajar disebabkan oleh beberapa faktor antara lain kesulitan belajar yang berasal dari faktor internal dan faktor eksternal. Faktor internal merupakan faktor yang berasal dari dalam diri mahasiswa itu sendiri yang terdiri dari aspek intelegensi yang berupa pemahaman konsep dan aspek kedua dari segi motivasi, minat, kesiapan dan perhatian. Faktor eksternal adalah faktor yang timbul dari lingkungan sekitar individu atau faktor yang datang dari luar diri individu. Faktor eksternal ini meliputi lingkungan keluarga, sarana prasarana dan lingkungan masyarakat. Berdasarkan data perolehan hasil kuesioner yang menunjukkan bahwa faktor diri sendiri menyababkan faktor penyebab dalam kesulitan belajar, faktor-faktor ini meliputi motivasi, keinginan yang asalnya berasal dari mahasiswa itu sendiri. Faktor sekolah dalam pengaruhnya dengan kesulitan belajar dengan nilai persentase $29,41 \%$. Sekolah dalam hal ini memfasilitasi mahasiswa dalam belajar yaitu dengan penyediaan sarana dan prasarana demi kelancaran perkuliahan. Masyarakat menjadi faktor ketiga dengan persentase $23,93 \%$ dan keluarga sebanyak $11,76 \%$.

Kesulitan belajar tidak selalu disebabkan faktor intelegensi, tetapi dapat juga karena faktor non intelegensi. IQ yang tinggi belum tentu menjamin keberhasilan dalam belajar. seorang mahasiswa tentu mempunyai IQ di atas rata-rata. Berdasar asumsi tersebut maka kesulitan belajar yang terjadi pada mahasiswa termasuk dalam "under achiever" yaitu prestasi rendah atau kurang. Mahasiswa tersebut memiliki IQ tinggi tetapi prestasi belajarnya rendah atau tidak dapat mencapai yang semestinya (berdasar tingkat kemampuannya). Sedangkan kelompok mahasiswa yang mengalami kesulitan belajar tersebut disebut sebagai "lower group" yaitu kelompok yang mempunyai prestasi di bawah rata-rata.

Faktor-faktor kesulitan belajar dapat berasal dari dalam diri mahasiswa sendiri seperti motivasi yang kurang, kebiasaan belajar kurang efektif dan kecakapan mengikuti kuliah kurang. Faktor lain berasal dari sekolah, yaitu karena faktor guru, bahan bacaan, kurikulum, kondisi gedung dan alat pelajaran. Keluarga juga merupakan faktor yang mempengaruhi kesulitan belajar, yaitu perhatian orangtua, suasana rumah tangga dan keadaan ekonomi. Faktor masyarakat seperti teman bergaul, aktivitas di masyarakat dan lingkungan tetangga juga mempengaruhi kesulitan belajar. Kesulitan dan minat belajar mahasiswa sering disertai dengan adanya penurunan nilai

Berdasarkan data penelitian yang didapat aspek psikologi dan jasmani atau pengaruh internal mempunyai pengaruh paling besar terhadap minat belajar mahasiswa yaitu dengan nilai persentase tertinggi $47,06 \%$. Aspek psikologi termasuk motivasi, perhatian, ketertarikan, bakat menjadi hal penting di dalam memperhatikan minat belajar mahasiswa, oleh karena itu penting bagi skateholders pendidikan khususnya kampus kerjasama keluarga mahasiswa untuk tetap dapat memperhatikan sikap psikologis mahasiswa demi tercapainya suatu tujuan pembelajaran. Peran serta lembaga pendidikan dalam meningkatkan minat belajar mahasiswa memiliki tingkat terpenting kedua dengan nilai persentase 35,29\%. Lembaga pemndidikan dalam hal ini kampus sebaiknya mempersiapkan segala sarana dan prasarana dalam kelengkapan belajar mahasiswa karena kelengkapan sarana dan prasarana dapat memicu mina belajar mahasiswa. Peran keluarga dalam meningkatkan minat belajar mahasiswa berada pada urutan ketiga yaitu dengan nilai persentase $23,53 \%$, masyarakat merupakan bagian hidup dari mahasiswa, masyarakat memeliki pengaruh besar terhadap apa yang diperoleh mahasiswa di masa dating, misalnya bagimana seorang mahasiswa bergaul dalam masyarakat juga dapat mempengaruhi tingkat belajar mahasiswa di kampus.ga sebaiknya lebih banyak mengambil andil dalam pendidikan seorang mahasiswa, dari data yang diperoleh, aspek masyarakat dalam peningkatan minat belajar mahasiswa mempunyai uruan terendah dengan dengan nilai persentase sebanyak $11,76 \%$, hal ini menunjukkan bahwa keluarga kurang memperhatikan anggota keluarganya 
dalam pendidikan. Mahasiswa lebih banyak bersama keluarga dibandingkan dengan masyarakat oleh karena itu sebaiknya keluarga memberikan perhatian khusus bagi anggota keluarganya dalam meningkatkan minat belajar.

Teori belajar konstruktivisme menekankan bahwa pengetahuan kita itu adalah konstruksi (bentukan) kita sendiri. Dalam hal ini proses belajar berpusat kepada siswa sebagai subjek belajar. Pengetahuan bukanlah suatu fakta yang tinggal ditemukan, melainkan suatu perumusan yang diciptakan oleh orang yang sedang mempelajarinya. Upaya untuk meningkatkan hasil belajar siswa hendaknya didukung dengan optimalisasi peran semua faktor pendukung hasil belajar, baik faktor internal maupun faktor eksternal. Sekolah harus mampu menciptakan sarana dan prasarana serta suasana belajar yang aktif dan menarik di sekolah. Dalam proses pembelajaran guru idelanya hanya menjadi fasilitator siswa dalam menemukan kompetensi yang diinginkan oleh guru dan lembaga pendidikan. Sementara siswa hendaknya memiliki kemandirian dalam belajar, tidak bergantung secara dominan terhadap guru. Komitmen untuk menciptakan suasana belajar yang dapat mengintegrasikan semua faktor yang mendukung keberhasilan belajar siswa harus dilakukan secara sadar, simultan dan berkesinambungan.

Berdasarkan teori ini dapat disimpulkan bahwa hasil penelitain yang didapatkan sesuai dengan teori di mana bahwa dalam minat belajar sebaiknya mahasiswa dapat mengandalkan dirinya berdasarkan kemampuan dan kompetensi-kompetensi yang mereka miliki sesuai dengan tuntutan abad 21, mahasiswa sebaiknya tidak hanya belajar tetapi dapat menciptakan dan menghasilkan sesuatu, tidak hanya memahami konsep yang ada.

Tabel 4.1 menunjukkan bahwa terdapat 6 mahasiswa yang mempunyai nilai B pada mata kuliah Fisiologi Tumbuhan dengan nilai persentase 35,29\%, 9 mahasiswa nilai $\mathrm{C}$ dengan persentase $11,76 \%$ dan 2 mahasiswa dengan nilai D persentase $11,76 \%$, kedua mahasiswa ini termasuk golongan tidak lulus. Berdasarkan hasil belajar tersebut, dapat dikatakan bahwa hasil belajar tersebut tergolong rendah, hal ini erat kaitannya dengan kesulitan dan minat belajar mahasiswa. Terdapa banyak faktor yang dapat mempengaruhi hal ini dan telah kita liahat pada bahasanbahasan sebelumnya di atas bahwa kesulitan dan minat belajar dapat dipengaruhi oleh faktor psikologi, keluarga, sekolah, dan masyarakat dengan sifat dan karakteristik masing-masing.

Ketika dihubungkan dengan hasil observasi yang dilakukan selama proses pembelajaran bahwa apa yang dilakukan mahasiswa pada saat proses pembelajaran dapat mempengaruhi hasil belajar dan apa yang mereka lakkan merupakan pengaruh-pengaruh dari kesulitan dan minat belajar mahasiswa. Hal ini diperkuat dengan adanya wawancara terbuka yang dilakukan dengan beberapa mahasiswa bahwa hal utama yang menjadi penyebab kesulitan dan minat belajar adalah sarana prasarana yang tidak memadai utamanya dari ruang belajar yang mereka tempati dan menjadi penyebab uama mereka tidak termotivasi untuk berlajar.

\section{KESIMPULAN}

1. Faktor yang mempengaruhi kesulitan belajar mahasiswa biologi kelas A angkatan 2013 pada materi Fisiologi Tumbuhan berasal dari 4 aspek yaitu dari diri sendiri, keluarga, sekolah, dan lingkungan masyarakat. Aspek diri sendiri mempunyai persentase tertinggi sebagai faktor yang mempengaruhi kesulitan belajar yaitu sebanyak 52,94\%, menyusul lingkungan sekolah 29,41\%, Lingkungan masyarakat 23,93\% dan lingkungan keluarga sebanyak $11,76 \%$.

2. Faktor yang mempengaruhi minat belajar mahasiswa biologi kelas A angkatan 2013 pada materi Fisiologi Tumbuhan berasal dari 4 aspek yaitu dari aspek jasmani dan psikologi, keluarga, sekolah, dan masyarakat. Aspek psikologi mempunyai persentase tertinggi sebagai faktor yang mempengaruhi minat belajar yaitu sebanyak 47,06\%, menyusul lingkungan sekolah 35,29\%, keluarga 23,53\% dan masyarakat sebanyak 11,76\%. 


\section{DAFTAR PUSTAKA}

Arfandi. 2014. https://anasarfandi.wordpress.com/2014/01/06/Faktor-Faktor yang Mempengaruhi Kesulitan Belajar Mahasiswa Pendidikan Teknik Sipil dan Perencanaan FT UNM (online). Diakses 8 Juni 2014.

Anonim. 2014. http://www.kancilku.com/Ind//index.php?option=com_content\&task=view\&id=300 (online). Diakses tanggal 13 Juni 2015.

Anonim. 2015. http://mitramahasiswa.blogspot.com/2012/10/Jenis-Jenis-Kesulitan-Belajar.html (online). Diakses 13 Juni 2015.

Arikunto. 2009. Dasar-Dasar Evaluasi Pendidikan. Jakarta: Bumi Aksara.

Departemen Pendidikan Nasional (Depdiknas). 2007. Tes Diagnostik. Jakarta: Diknas. Djaali. 2007. Pengukuran Dalam Bidang Pendidikan. Jakarta: Gramedia Widia Sarana. Indahati. 2011. Pengembangan Tes Diagnostik Biologi kelas XI IPA SMA Di Kabupaten Luwu Tesis. Makassar. Pascasarjana UNM Makassar.

Muhibbin, S. 2009. Psikologi Pendidikan dengan Pendekatan Baru. Bandung: PT Remaja Rosdakarya.

Purwanto, N. 2009. Psikologi Pendidikan. Bandung: PT. Remaja Rosdakarya.

Rusman. 2010. Model-Model pembelajaran, Mengembangkan Profesionalisme Guru. Jakarta: Rajawali Press.

Santosa, B. 2007. Biologi SMA Kelas XI. Jakarta: Inter Plus.

Sardiman A. M. 2009. Interaksi dan Motivasi Belajar Mengajar. Jakarta: CV. Rajawali.

Shadiq, F. 2007. Psikologi Pembelajaran Matematika di SMA. Yogyakarta: Pusat Pengembangan dan Pemberdayaan Pendidik dan Tenaga Kependidikan Matematika.

Slameto. 2010. Belajar dan faktor-faktor yang mempengaruhinya. Jakarta. Rineka Cipta Trianto. 2009. Model Pembelajaran Terpadu dalam Teori dan Praktek. Surabaya: Pustaka Ilmu.

Uli, F. 2010. Upaya Peningkatan Minat Belajar Siswa dalam Pembelajran PAI Materi Pokok Ilmu Tajwid Melalui Metode Drill Kelas VII G di SMP Negeri 1 Kragan. (http://jtptiaingdl-ulifatmawati-6107-1-skripsi-p.pdf, diakses 27 juni 2015). 